\title{
Resistance Evaluation and Growth of Carbon Nanotubes
}

\author{
Fumiyuki Nihey Non-member (NEC Fundamental and Environmental Research Laboratories) \\ Hiroo Hongo Non-member (NEC Fundamental and Environmental Research Laboratories) \\ Masahiko Ishida Non-member (NEC Fundamental and Environmental Research Laboratories) \\ Hidefumi Hiura Non-member (NEC Fundamental and Environmental Research Laboratories) \\ Yukinori Ochiai Non-member (NEC Fundamental and Environmental Research Laboratories)
}

Keywords: carbon nanotubes, resistivity, contact resistance, chemical vapor deposition

Carbon nanotubes (CNTs) have attracted much attention as possibly essential ingredients for future nanoelectronics because of their very narrow diameters of an order of nanometers, possible engineering of electronic properties, ballistic transport, and large current capacity. In order to clarify the advantage of CNTs, benchmark study should be addressed with well-established Si-MOSFET technologies. In addition, device fabrication methods with CNTs should be developed in order to step toward their practical use.

We investigated electronic transport in single-wall carbon nanotubes attached to multiple electrodes. Resistance measurements using a pair of electrodes with different gaps enabled nanotube resistivity to be separately evaluated as well as contact resistance. We found that the resistivity depends on nanotube diameter. Electrodes with gold or palladium exhibit contact resistance of the order of $10 \mathrm{k} \Omega$. Contact resistance is insensitive to back gate voltage, contrary to the Schottky-barrier transistor model.

We also have investigated the intrinsic transconductance of CNTFETs with CNTs grown by chemical vapor deposition (CVD). The measured transconductance at a drain voltage of $-1 \mathrm{~V}$ was $8.7 \mu \mathrm{S}$ for a CNT with a diameter of $1.5 \mathrm{~nm}$. Very high intrinsic transconductance of $20 \mu \mathrm{S}$ was estimated by considering the contribution of parasitic resistance. Apparent and intrinsic transconductance per unit channel width were $5800 \mu \mathrm{S} / \mu \mathrm{m}$ and $13000 \mu \mathrm{S} / \mu \mathrm{m}$, respectively. These are considerably larger than those for the state-of-the-art $\mathrm{Si}$ MOSFETs. We expect the performance of CNTFETs will advance further by improving CNT quality and by optimizing device structures ${ }^{(1)}$.

We have also developed a novel method for iron nanoparticle synthesis that enables easy control of both the positions and diameters of the nanoparticles with precision significantly smaller than lithography limit, and have demonstrated diameter- and position-controlled CNT growth by these nanoparticles. We patterned iron particles having a $1.7 \mathrm{~nm} \pm 0.6 \mathrm{~nm}$ diameter distribution within a positioning accuracy of $\pm 5 \mathrm{~nm}$ by means of "lithographically-anchored nanoparticle synthesis (LANS)" $\operatorname{method}^{(2)}$, consisting of dot-patterning of electron-beam resist mixed with organic iron, phase-separation by temperature elevation, and carbon removal by oxidation. The particle size can be controlled by iron content in electron-beam resist and pattern size. The

(1) F. Nihey et al., Jpn. J. Appl. Phys. Vol.43, L1356 (2004)

(2) M. Ishida et al., Jpn. J. Appl. Phys. Vol.43, L1356 (2004)

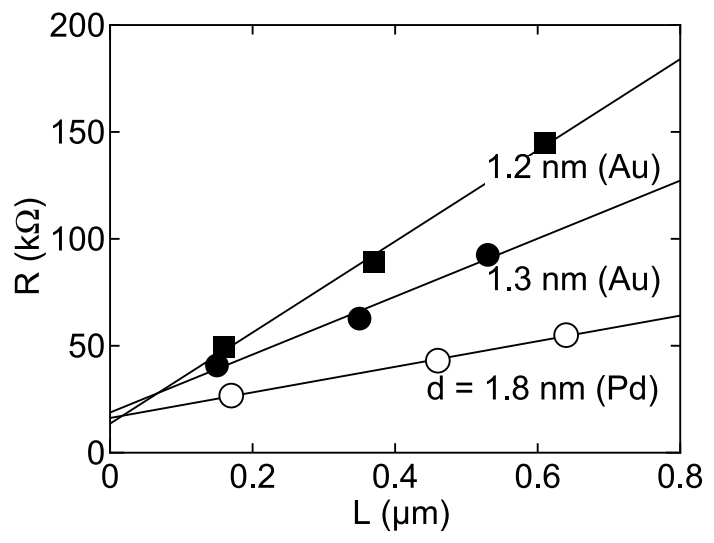

Fig. 1. Lentgh $(L)$ dependence of two-terminal resistance $(R)$ for three carbon nanotubes with different diameters and contacts

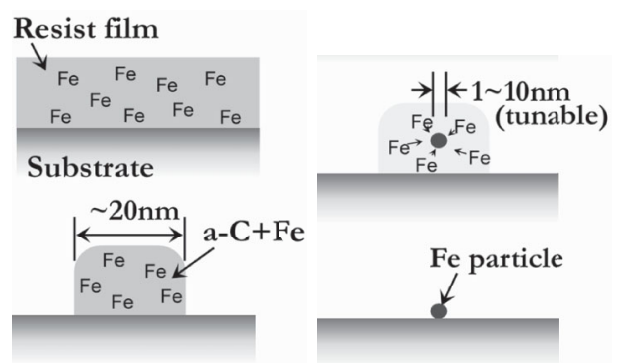

Fig. 2. Fabrication process of lithographicallyanchord nanoparticle synthesis (LANS)

position of the particles are limited by initial dot positions. CNTs were successfully grown by ethanol CVD. This method is readily applicable to the fabrication of high-performance CNTFETs. 


\title{
カーボンナノチューブの抵抗評価と合成 \\ 非会員 二瓶 史行* 非会員 本郷 廣生* \\ 非会員 石田 真彦* 非会員 日浦 英文 ${ }^{*}$ \\ 非会員 落合 幸徳*
}

\author{
Resistance Evaluation and Growth of Carbon Nanotubes \\ Fumiyuki Nihey*, Non-member, Hiroo Hongo*, Non-member, Masahiko Ishida*, Non-member, \\ Hidefumi Hiura*, Non-member, Yukinori Ochiai*, Non-member
}

\begin{abstract}
We have investigated electronic transport in single-wall carbon nanotubes attached to multiple electrodes. Resistance measurement using a pair of electrodes with different gaps enabled separate evaluation of nanotube resistivity and contact resistance. We found that the resistivity depends on nanotube diameter. Electrodes with gold or palladium exhibit similar contact resistance with an order of $10 \mathrm{k} \Omega$. Contact resistance is insensitive to back gate voltage, contrary to the Schottky-barrier transistor model. We also demonstrated the top-down control of diameter and position of Fe catalysts by means of "lithographically anchored nanoparticle synthesis (LANS)" for nanotube growth. Chemical vapor deposition by using these patterned particles successfully produced single-wall carbon nanotubes.
\end{abstract}

キーワード : カーボンナノチューブ, 抵抗率, コンタクト抵抗, 気相成長法

Keywords: carbon nanotubes, resistivity, contact resistance, chemical vapor deposition

\section{1.はじめに}

カーボンナノチューブ (CNT) は产の直径がナノメート ル程度と非常に細いシームレスな円筒状グラファイト物質 である。光の細さと構造上の面白さから,ナノテクノロジー を紹介する際によく引き合いに出される。材料物性的にみ ても従来にはない興味深い特性を示すことから，樣々な観 点から基礎研究・応用研究がなされてきた。本稿では, カー ボンナノチューブのトランジスタ応用に向けた抵抗評価（抵 抗率，コンタクト抵抗），トップゲート構造 CNTFET の特 性について述べる。また，位置制御性と直径制御性を向上 させた Fe 触媒形成法およびこれを用いたナノチューブの CVD 成長について述べる。

\section{2. エレクトロニクス材料としてのナノチューブ}

我々はカーボンナノチューブが将来のナノエレクトロニク スのキー材料として役に立つ事を期待している。ナノチュー ブは従来の半導体材料とは異なった構造的・電気的特長を 持っていることから，これらを生かした機能デバイスとし

\footnotetext{
* NEC 基礎・環境研究所

干 305-8501 つくば市御幸が丘 34 番地

NEC Fundamental and Environmental Research Laboratories 34 Miyukigaoka, Tsukuba 305-8501
}

て発展する可能性を有している。 カーボンナノチューブの構造的な特長として ,(1) 自己 組織的に形成されるナノ構造材料である事，(2) 機械的に 柔軟である事,(3) 化学的に安定な表面を持つ事,(4) 良い 熱伝導材料である事, などがある。ナノチューブに似た材 料として各種半導体 ( $\mathrm{Si}, \mathrm{InP}$ など) のナノワイヤがある。 ナノチューブもナノワイヤと同樣に VLS 機構により成長 すると考えられているが, ナノワイヤに見られる直径の変 動 (テーパリング) や格子欠陌が少ない。これはグラファ イト構造が強固であるために , テンプレートの構造を保っ たまま成長するためと考えられている。電子伝導にとって 直径変動や転移は散乱体となるが, ナノチューブでは产の 影響が少ない事になる。従来のナノ構造では移動度低下が よく問題となるが, ナノチューブは 1 次元材料であるにも かかわらず大きな問題とはならないのか驚きである。機械 的に柔軟である特長は, フレキシブルデバイス, MEMS • NEMS 応用に有利であると考えられる。サブミクロンレベ ルの曲率半径で曲げても電気特性はほとんど変らない。化 学的に安定である事は, ナノ構造にとって重要であり，多 樣な材料をナノチューブ界面に持ってくることができると 考えらえる。トランジスタ応用においてはゲート絶縁膜が 重要な役割を果すが, チャネルとの界面が非常に重要であ る。ナノチューブの表面にはダングリングボンドが存在し 
ないので従来とは違った考え方で絶縁膜を選択することが できる。熱伝導性は炭素間結合か漒固である事を反映して いる。これはデバイスを高バイアスで動作させる場合に重 要で, デバイス内部で発生する熱を基板方向のみならずチャ ネル方向にもすみやかに放熱できると考えられる。

電気的な特長としては, (1) 電子構造が直径やカイラリ ティによって規定される事,(2) 非常に大きい許容電流密度 を持っている事,(3) 電子速度が非常に大きくバリスティッ ク伝導が期待される事などがある。基本的にグラファイト の物性を引き継いでいるため, 安定でありかつ良好な導電 性を示す。ナノチューブの特長は直径や巻き方により電子 構造が制御できる点にある。これはナノメータースケール の円筒状になっているため, 円周方向の量子サイズ効果が 無視できないほど大きいためである。グラファイト自身は エネルギーギャップがゼロの半導体 (半金属) であるが , こ れに周期境界条件が加わると，ゼロギャップに対応する波 数か許容か非許容かによって金属的あるいは半導体的にな る。また , 半導体の場合には直径に反比例してバンドギャッ プか変化する。現在の技術では構造を制御するところまで は至っていないが，これが実現した際には所望の電気状態， バンドギャップを持つナノチューブをデザインできること になる。また，電流密度については $10^{9} \mathrm{~A} / \mathrm{cm}^{2}$ 程度まて許 容できる。この值は銅などがエレクトロマイグレーション を起こす電流密度より 2 林大きい。この特性により，非常

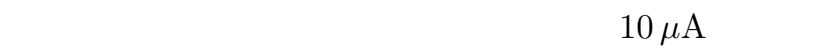
事ができる。

\section{CNT の抵抗率・ コンタクト 抵抗分離評価}

ナノチューブをトランジスタのチャネル材料として用い る場合，CNT の抵抗率，コンタクト抵抗など基本特性の理 解が重要である。しかしながら CNT に対して通常の 4 端 子測定は行なえない。電極の存在が CNT に大きく影響を 及ぼすためである。光こで我々は一本の半導体単層 CNT に 複数のオーミック電極を間隔を変えて設置した試料を用い， 抵抗の長さ依存性から抵抗率とコンタクト抵抗を見積った。 兴の結果，(1) 電極接触領域の抵抗,(2) 電極近傍での抵抗 増加，(3) CNT 抵抗率の直径依存に関する知見を得た。ま た , バックゲートによる抵抗率およびコンタクト抵抗の変 調を観測した。

図 1 に実験に使用した素子を示す。試料の作製方法は， 我々がトランジスタを作製する方法を踏襲した。すなわち， 高濃度ドープ $\mathrm{Si} / \mathrm{SiO}_{2}$ 基板上に形成した $\mathrm{Fe} / \mathrm{Al}$ 触媒パタ ンから CVD により CNT を選択成長させた。CVD にはメ タンガスを用いている。CVD 後, オーミック電極を電子 ビーム露光・真空蒸着・リフトオフを用いて形成した。電極 金属は $\mathrm{Au}$ と Pd を採用した。両者とも $\mathrm{P}$ 型 CNT に対し て良好なオーミック材料であると考えられている。評価対 象として半導体的な振舞いをする単層ナノチューブ (バッ クゲートに対して伝導度か変調するナノチューブ) を選択 した。
まず，四探針法および二探針法による測定を行なった。四 探針法では, 最外の電極対に電流を流し，内側の電極対で 電圧降下を測定する。二探針法では内側の電極対に電流を 流し，同じ電極対を用いて電圧降下も測定する。実験の結 果，両者の差は $500 \Omega$ 程度であり，電極自身や電極- CNT 接触部の抵抗は CNT の抵抗に比べて十分に小さい事がわ かった。

直径・電極材料が異なる CNT の，長さ $L$ に対する二探 針抵抗 $R$ の依存性を図 2 に示した。 $R$ は $L$ に対して線型 に変化し, CNT の長さに応じて抵抗か変化する事がわか る。長さに応じて抵抗か増加する事から，このナノチューブ の場合は拡散的な伝導を示している事がわかる。また，Au および $\mathrm{Pd}$ ともに数 $10 \mathrm{k} \Omega$ のオフセット抵抗か認められる。 これは電極への電荷移動等により電極近傍の CNT の抵抗 か増加したためと考えている。

図 2 における各データの傾きから得られる CNT の抵抗 率の, 直径に対する依存性を図 3 に示した。CNT の抵抗 率は直径の増加にともない減少する事がわかる。データが 少ないが, CNT の直径 $d$ に対する抵抗率 $\rho$ の变化から, $\rho \propto 1 / d^{2}$ の関係が示唆される。これは散乱過程が直径に 依存するためと考えられる。フォノン散乱の散乱時間が直 径に対して変化する計算結果か報告されているが, 我々の CNT を支配する散乱がフォノンによるものか，あるいは 欠陥などの外因的なものに由来するのか今後詳細に検討す る必要がある。

バックゲートの電圧 $V_{\mathrm{G}}$ を変化させたときの抵抗の変化 を図 4 に示す。ゲート電圧によって，兴の傾きが変化して いる事から, ナノチューブの抵抗率が変化している事がわ かる。弚の一方て切片も変化しており，ゲート電圧を正方 向に変化させると減少していく樣子が見てとれる。この結 果から，バックゲートによってナノチューブの抵抗率とコン タクト抵抗が同時に制御されていると結論づけられ关うだ。
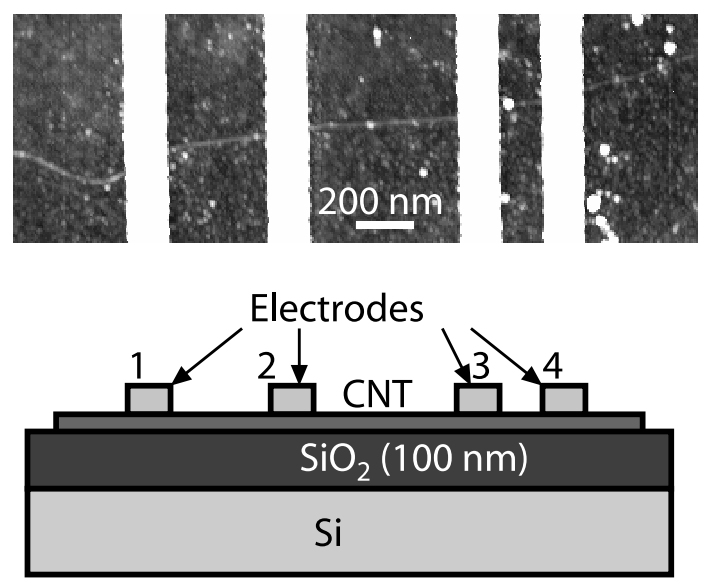

図 1 Four-terminal carbon nanotube device for evaluation of the CNT resistivity and contact resistance. (Upper: atomic force microscopy image. Lower: cross-sectional structure) 
しかしながらバックゲート構造のデバイスにおけるこの 種の実験は慎重に吟味されるべきである。なぜならこのデ バイスの場合, 酸化膜厚が $100 \mathrm{~nm}$ もあるため, コンタク 卜電極近傍のキャリアは遮蔽効果により十分に制御できな い可能性があるためである。光のため，バックゲートで制 御される実効的なナノチューブ長は実際のナノチューブ長 より短かくなっている可能性がある。シミュレーションで

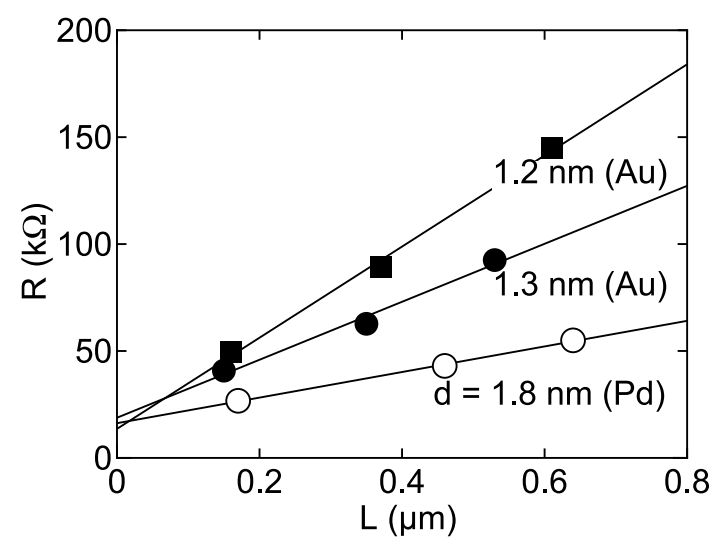

図 2 Lentgh $(L)$ dependence of two-terminal resistance $(R)$ for three carbon nanotubes with different diameters and contacts

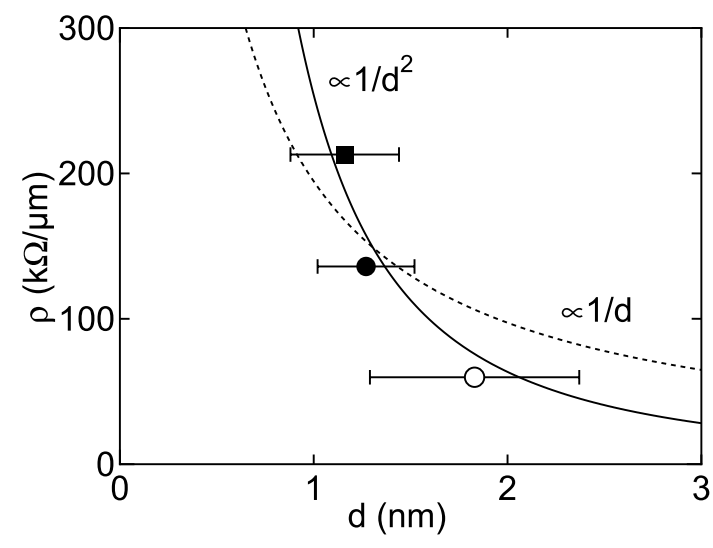

図 3 Diamter $(d)$ dependence of carbon nanotube resistivity $(\rho)$

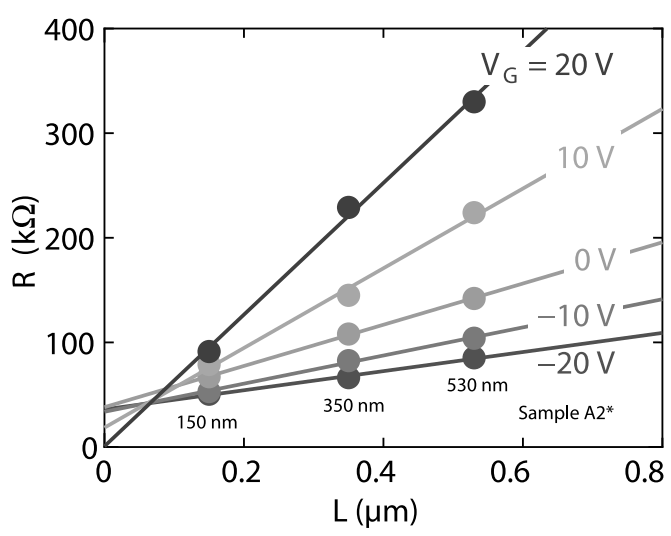

図 4 Back gate $\left(V_{\mathrm{G}}\right)$ dependence of two-terminal resistance
は午の長さは酸化膜程度である。この問題を回避するため には酸化膜をさらに薄くする必要があると考えられる。

\section{4. トップゲート構造 CNTFET}

トランジスタとしての特性を評価するためにトップゲー 卜構造 CNTFET を作製し，光の特性を評価した。デバイス の構造を図 5 に示す。デバイス作製には前節と同樣に $\mathrm{Fe} / \mathrm{Al}$ 触媒 ${ }^{(1)}$ を用いて $\mathrm{Si} / \mathrm{SiO}_{2}$ 基板上に選択的に CVD 成長させ た単層 $\mathrm{CNT}$ をチャネルとして用いた。 $\mathrm{SiO}_{2}$ の膜厚は 100 $\mathrm{nm}$ である。また， $\mathrm{TiO}_{2}$ をゲート絶縁膜としたトップゲー 卜構造を用いた ${ }^{(2)(3)}$ 。 $\mathrm{TiO}_{2}$ は蒸着した金属チタンを自然 酸化する事によって形成した。

$\mathrm{CNT}$ 直径 $1.5 \mathrm{~nm}$, チャネル長 $1 \mu \mathrm{m}$, ゲート長 $280 \mathrm{~nm}$ の CNTFET におけるドレイン電流 $I_{\mathrm{D}}$ のトップゲート電圧 $V_{\mathrm{G}}$ 依存性 $\left(\right.$ ドレイン電圧 $V_{\mathrm{DS}}=-1 \mathrm{~V}$, 基板電圧 $V_{\mathrm{SUB}}=0$ $\mathrm{V})$ を図 6 に示す。このデバイスは $\mathrm{p}$ 型ディプレッション FET の特性を示し (閾値電圧〜 $0.6 \mathrm{~V}$ ) , 相互コンダクタンス は $g_{\mathrm{m}}=8.7 \mu \mathrm{S}$ ，また $V_{\mathrm{DS}}=-100 \mathrm{mV}$ において $g_{\mathrm{m}}=1.4$ $\mu \mathrm{S}$ となった。この值は我々がレーザー蒸発法により生成し た CNT を用いた CNTFET ${ }^{(2)}$ で得た值 $\left(g_{m}=0.32 \mu \mathrm{S}\right.$ ， $\left.V_{\mathrm{DS}}=100 \mathrm{mV}\right)$ を大きく上回る。このデバイスはゲート 領域以外の余分な領域があるため寄生抵抗分が大きい。こ の值 $(130 \mathrm{k} \Omega)$ を排除した場合の相互コンタクタンスを計算 すると， $20 \mu \mathrm{S}$ となる。これから，単位ゲート幅あたりの $g_{\mathrm{m}}$ を計算すると $13000 \mu \mathrm{S}$ と非常に大きい值となる。この 値はSi-MOSFET より 1 桁程度大きな值である。CVD 法 を用いた CNTFET により，Si-MOSFET を大幅に上回る 特性が期待できる。

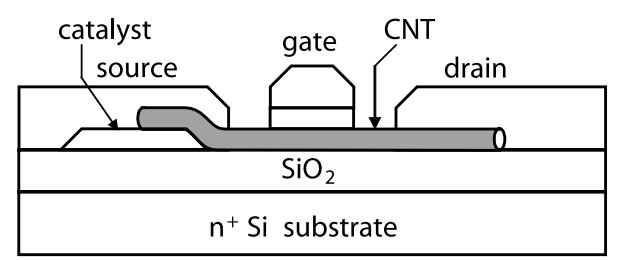

図 5 Device structure for top-gate carbon nanotube field-effect transistor

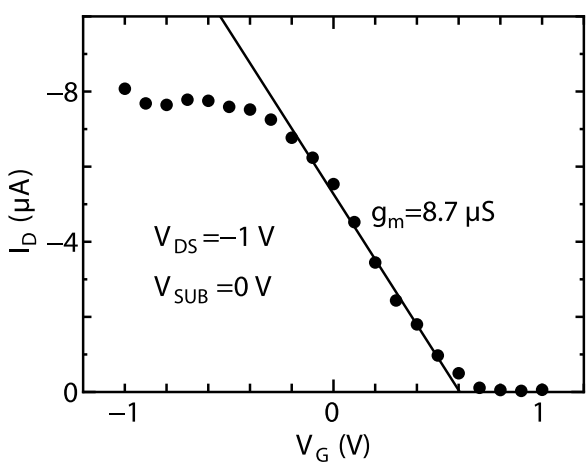

図 $6 \quad I_{\mathrm{D}}-V_{\mathrm{G}}$ characteristics of the top-gate CNTFET 

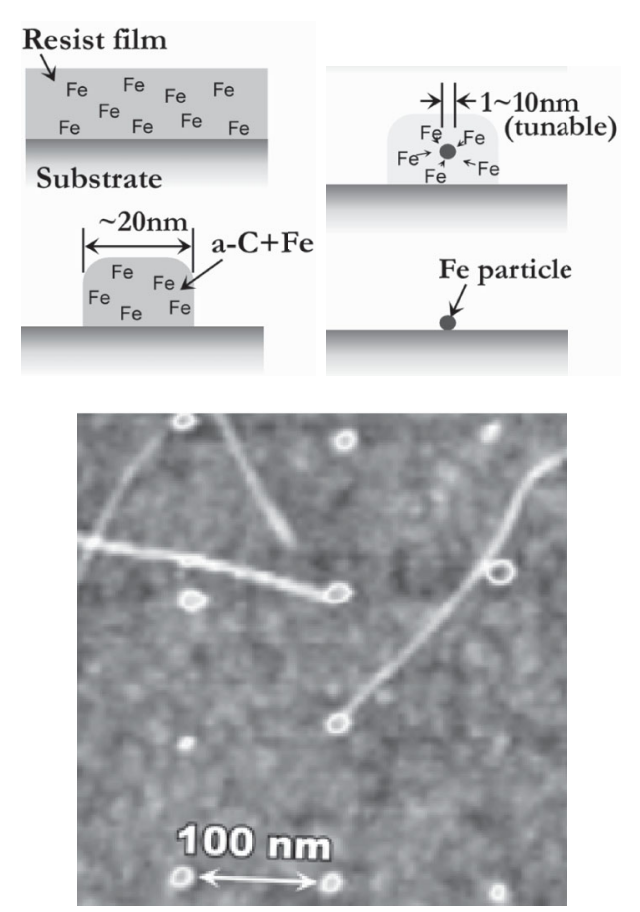

図 7 Upper: fabrication process of lithographically-anchord nanoparticle synthesis (LANS). Lower: atomic-force microscopy image of carbon nanotubes grown from LANS Fe particles

Si デバイスと比較するためには他の指標（サブスレショ ルド特性など）に関しても比較していく必要がある。ナノ チューブデバイスの可能性を探るため, 今後も詳細な評価 をしていきたいと考えている。

\section{CNT 精密成長に向けた触媒微粒子の高精度制御}

我々は単層カーボンナノチューブの成長制御を目的とし て, 高い粒径制御性と位置制御性を持つ新しい触媒微粒子の 作製方法 (Lithographically-Anchord Nanoparticle Synthesis; LANS) を提案した ${ }^{(4)}$ 。この方法は,(1) 微量の有 機金属化合物を添加した電子線 (EB) レジストを用いてシ リコン基板上に微細ドットパタンを形成，(2) 不活性雾囲 気での加熱処理によってドットパタン内の金属を析出，(3) 酸化雰囲気での加熱処理によって不要な炭素成分を除去す るステップからなる。パタンサイズと金属濃度などを制御 することにより，リソグラフィ限界以下の粒子径を持つ触 媒微粒子を容易に形成することができる。

具体的な方法を以下に示す。まず，モノクロロベンゼン 溶媒の p-メチル-メチルアセトキシカリックス [6] アレン (1wt\%) に Fe(III) アセチルアセトナートを $0.1 \mathrm{wt} \%$ 添加 したレジスト溶液をシリコン基板 $\left(\mathrm{SiO}_{2}\right.$ 膜被覆 $)$ 上にスピ ンコートし，約 $30 \mathrm{~nm}$ 厚のフィルムを得る。光して， EB 露光により径 $20 \mathrm{~nm}$ 程度のドットを作製する。次に , 真 空中 $650^{\circ} \mathrm{C}$ で加熱処理するとパタン中に鉄微粒子が析出す る。弚の後，大気を導入して炭素成分を除去すると，パタ
ンがあつた位置に平均 $2 \mathrm{~nm}$ 径の Fe 粒子が残る。粒子径は 有機金属化合物の濃度やレジスト膜厚, 露光量などにより 制御することができる。

この方法により作製した触媒を用いてカーボンナノチュー ブを形成することに成功した (図 7)。平均粒径 $1.7 \pm 0.6$ $\mathrm{nm}$ の鉄微粒子を用いて, エタノールを用いた熱分解 CVD $\left(750^{\circ} \mathrm{C}, 1\right.$ 分) を行なった結果, CNT の成長を確認した。 ラマン分光と AFM による直径評価から, 平均の直径が $1.3 \pm 0.4 \mathrm{~nm}$ の CNT が成長していることがわかった。

\section{6. おわりに}

課題として, 材料としての精密成長 (金属半導体分離成 長，直径制御），安定なドーピングなどによるしきい值精 密制御，コンタクト技術，保護膜，ゲート絶縁膜技術など か課題として残っている。これらが解決することによって， ナノチューブのエレクロトニクス応用の可能性が広がって くると考えられる。

謝 辞

本研究の一部は NEDO より JFCC に委託された経済産 業省「ナノカーボン応用製品創成プロジェクト」によって 行なわれた。

(平成 17 年 10 月 24 日受付, 平成 18 年 1 月 5 日再受付)

\section{文献}

(1) H. Hongo, F. Nihey, T. Ichihashi, Y. Ochiai, M. Yudasaka, and S. Iijima: "Support materials based on converted aluminum films for chemical vapor deposition growth of singlewall carbon nanotubes", Chem. Phys. Lett., Vol.380, pp.158164 (2003)

( 2 ) F. Nihey, H. Hongo, M. Yudasaka, and S. Iijima: "A Top-Gate Carbon-Nanotube Field-Effect Transistor with a Titanium-Dioxide Insulator", Jpn. J. Appl. Phys., Vol.41, Part 2, No.10A, pp.L1049-L1051 (2002)

( 3 ) F. Nihey, H. Hongo, Y. Ochiai, M. Yudasaka, and S. Iijima: "Carbon-Nanotube Field-Effect Transistors with Very High Intrinsic Transconductance", Jpn. J. Appl. Phys. Vol.42, Part 2, No.10B, pp.L1288-L1291 (2003)

(4) M. Ishida, H. Hongo, F. Nihey, and Y. Ochiai: "DiameterControlled Carbon Nanotubes Grown from Lithographically Defined Nanoparticles", Jpn. J. Appl. Phys., Vol.43, No.10B, pp.L1356-L1358 (2004)

二 瓶 史 行 (非会員) 1987 年大阪大学大学院理学研究科博

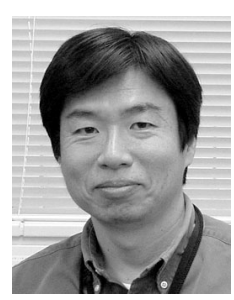
士前期課程修了。同年より日本電気 (株) 入社。 化合物半導体を用いた微細構造素子の研究開発に 従事。現在，カーボンナノチューブ応用に関する 研究開発に従事。理学博士 (大阪大学)。 
本 郷 廣 生 (非会員) 1998 年日本電気 (株) 入社。現在, カ一 ボンナノチューブのエレクトロニクス応用に関す る研究開発に従事。工学博士 (東京工業大学)。

石田 真 彦 (非会員) 1995 年筑波大学第三学群物質・分子工 学専攻卒。1999 年同大大学院工学研究科博士課程 修了。同年日本学術振興会特別研究員。2000 年日 本電気 (株) 基礎研究所入社。以来, 超微細電子 線レジストの開発, 荷電粒子ビームを用いた三次 元微細加工, CNT 応用研究に従事。博士 (工学)。
日 浦 英 文 (非会員) 1992 年早稲田大学大学院理工学研究

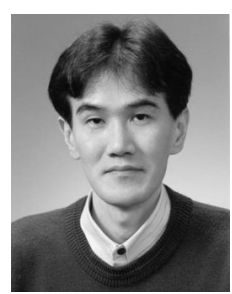
科博士課程修了。同年日本電気 (株) 入社。カー ボンナノチューブ, クラスターなどのナノ材料の 研究に従事。現在, ナノチューブのドーピング技 術の研究開発に従事。

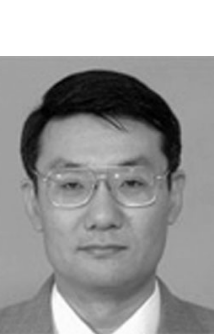

(非会員) 1986 年大阪大学基礎工学研究科博士 課程修了。工学博士。同年日本電気 (株) 入社。 基礎研究所配属。1989-1990 年ケンブリッジ大学 客員研究員。2005 年 9 月より (独) 科学技術振 興機構プログラム主管。電子・イオンビーム加工 とナノデバイス・CNT エレクトロニクス応用に 従事。 